\title{
Species Composition and Vegetation Structure in Natural Park PT Badak LNG, Bontang, East Kalimantan
}

\author{
Sudrajat ${ }^{1, *}$ Medi Hendra ${ }^{1}$ Sus Trimurti ${ }^{1}$ Lariman $^{1}$ Sudiastuti $^{1}$ \\ ${ }^{1}$ Department of Biology, Faculty of Mathematics and Natural Sciences, Mulawarman University, Jalan Barong \\ Tongkok No. 4, Samarinda 75123, East Kalimantan, Indonesia. \\ *Corresponding author. Email: sudrajat.fmipa@gmail.com
}

\begin{abstract}
Forest ecological studies in Natural Park PT Badak Bontang, East Kalimantan has been carried out with the transect method. Vegetation observation was done on the transect line made by plot size $20 \times 20$ meter, and the distance between the plots is 100 meters. This study would be covered on species composition and species importance values. The forest structure could be seen from diameter and height stem classes, where commonly have been still some big tree with diameter $>100 \mathrm{~cm}$ and height $50 \mathrm{~m}$ tall. Meranti types are the main types of community constituents. These species include Shorea daspyphylia, S.hemsleyana, S. gibbosa, S. kunstteri, S.leprosula, S. macroptera, S.ovalis, S.parvifolia, S.pinanga, S.johorensis, S.ovata, S. pauciflora, S.pubistyla, S.seminis. Based on the Species Importance Value-s index rankings, respectively, Anthocephalus sp. with a value of 27.03 , followed by S. kunsteri of 16.59 , Memecylon borneensis of 15.78, S. alutaceae of 14.77, Syzygium sp. of 14.138 and Ficus sp. of 10.55. In the seedling, the level is dominated by pioneer types such as Syzygium spp., Litsea spp., Memecylon borneensis, Syzygium spp., Litsea spp. The kind of Dipterocarpaceae seedling is scarce. The type of Dipterocarpaceae seedling is short. The regeneration failure of these Dipterocarpaceae species in the future will alter the structure and composition of the plant species and is driven by the dominance of seedlings of pioneer groups.
\end{abstract}

Keywords: Species Composition, Vegetation Structure, Species Importance Values

\section{INTRODUCTION}

Natural Park area of 7.4 ha located in PT Badak site represents the original ecosystem type of tropical rain forest of lowland of East Kalimantan. This forest is a natural and historical monument before the existence of PT. Badak NGL. This forest's presence plays a vital role as a regulator of the ecological balance in the project footprint that unites the industrial activities and the natural environment to look harmonious, comfortable, natural and beautiful. Based on a topographic map scale of 1: 500, Natural Park area heights ranging from 15-45 $\mathrm{m}$ above sea level with geomorphological conditions ranging from flat to sloping or hilly.

The condition of the location overlays are distinguished on Natural Park natural vegetated forest site of 6 ha, and 1.4 ha are shrubs. This Park, located within the PT Badak NGL complex of $7.4 \mathrm{Ha}$, is an effort to conserve the company's biodiversity of lowland tropical forest. Characteristics of existing plants is a mixture of lowland and coastal communities. This forest results from the fragmentation of Natural forest in Bontang area since 1972, which initially intact became separated and isolated to form a small ecosystem. Based on Gunawan and Prasetyo, 2013, this process can be categorized as a result of habitat fragmentation. Fragmentation impacts the composition, species diversity, dynamics and ecosystem function $[1,2]$.

Based on the estimated age of trees conducted by the IPB Bogor team in 1995 to the plants in Natural Park, several trees are older than 100 years. Some of these plant species are commonly found in primary forests such as Canarium spp., Litsea spp., Bischofia spp., Eugenia spp., Lophopetalum spp., Ficus spp. etc. The oldest tree (estimated to be 535 years old) is Canarium caudatum. In the Natural Park area, there are potential mother trees as a seed source for other planting activities from the inventory that has been done. 
There are 18 protected tree species located in the Natural Park area PT. Badak NGL Bontang. The types are Alstonia scholaris (Pulai), Aquilaria malaccensis (Karas), Diospyros buxifolia (Rambai punai), Diospyros coriacea (black charcoal), Diospyros rigidus (Carbon wood), Diospyros sumatrana (Kayu arang), Diospyros toposioides (Carbon wood), Drybalanops sp. (Marakatan), Duabanga moluccana (Benuang laki), Dyera costulata (melabuai), Eurycoma longifolia (Pasak Bumi), Eusideroxylon zwageri (Ulin), Fagraea fragrans (Tembesu), Flacourtia rukam (Rukam), Ganua motleyana (Kemalao), Lophopetalum beccarianum (Perupuk), Shorea leprosula (Lempung lahung) and Styrax macrocarpa (Rice-rice).

The adverse effects of forest fragmentation and isolation are expected to alter forest structure and plant communities, jeopardizing biodiversity, regeneration capacity, and vitality of forests [3]. Loss of forest biodiversity may seriously affect forest ecosystems' functioning (i.e., the activities, processes, or properties of woods, such as decomposition of organic matter, soil nutrient cycling, and water retention). Consequently, the forest's ability to provide ecosystem services [4]. Ecosystem services have been defined as the benefits people obtain from ecosystems and categorized into four broad categories. These include provisioning services such as food, water, timber, and fiber; regulating services that affect climate (e.g., though carbon sequestration), pollination, biological pest control, floods, disease, wastes, and water quality; cultural services that provide recreational, aesthetic, and spiritual benefits; and supporting services such as soil formation, photosynthesis, and nutrient cycling [5].

The natural regeneration process in the forest can occur after a light entering the soil surface. The creation of a gap or forest opening that occurs due to the fall or the death of a big tree is the beginning of regeneration or regeneration.

The regeneration of a species encompasses the production and dispersal of seeds, their germination, and subsequently the juveniles' growth until they reach maturity and start producing seeds themselves. At any moment in the regeneration process, an individual may die, for example, following predation or due to adverse environmental conditions. The failure of a species to regenerate will ultimately result in its (local) extinction.

The study provides detailed ecological characteristics of the vegetation structure of Natural Park PT Badak NGL Bontang and aids in understanding the spatial distribution of vegetation descriptors for biodiversity conservation and management.

\section{MATERIALS AND METHODS}

\subsection{Study Area}

This study held in natural park of $7.4 \mathrm{Ha}$ in PT Badak NGL Bontang, East Kalimantan (Figure 1).

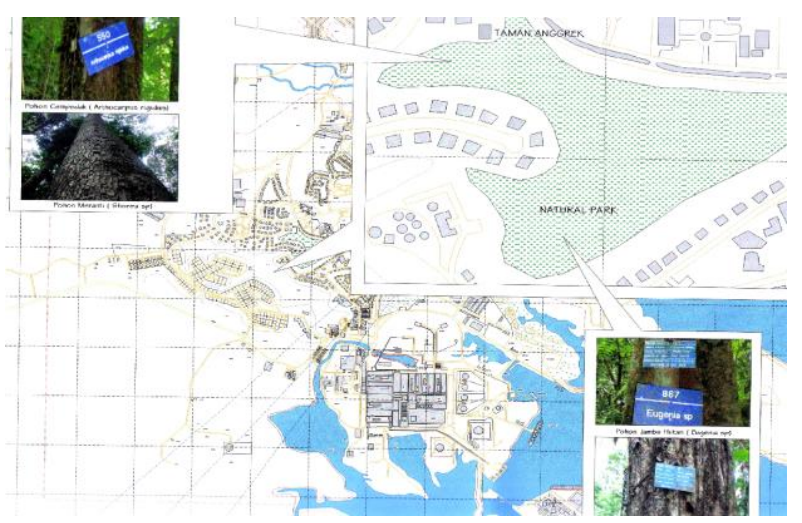

Figure 1 Study plot at Botanical Park PT Badak NGL Bontang East Kalimantan, Indonesia.

\subsection{Method}

Vegetation observation was done on the transect line made by plot size $20 \times 20$ meters. The distance between the plots is 100 meters. The data collection taken in this observation is the type of tree with a diameter size above $10 \mathrm{~cm}$. In this sample plot, establish some sub-plots, are $20 \mathrm{~m} \times 20 \mathrm{~m}$ for tree stratum (diameter at breast height/dbh $\geq 20 \mathrm{~cm}), 10 \mathrm{~m} \times 10 \mathrm{~m}$ for pole stratum $(\mathrm{dbh}$ $10-19.9 \mathrm{~cm}$ ), $5 \mathrm{~m}$ x $5 \mathrm{~m}$ for sapling stratum (dbh 2-9.9 $\mathrm{cm}$ ), and $2 \mathrm{~m} \times 2 \mathrm{~m}$ for seedling stratum $(\mathrm{dbh}<2 \mathrm{~cm}$ and height $<1.5 \mathrm{~m}$ ). For unidentifiable types of vegetation, plant parts are taken for later identification. Data were analyzed for calculating tree density (N/ha), Important Value Index (IVI), Diversity Index (H') from ShannonWiener, and to identify the stand structure of Natural Park forest.

\section{RESULTS AND DISCUSSION}

\subsection{Species Composition}

The wealth of trees in the natural forest is very high, where the results of identification and determination 3643 trees are consisting of 415 species and 56 tribes plants. Among these species are Aquilaria malaccensis, which is included in Appendix II status according to CITES and protected trees based on Government Regulation No. 7/1999 dated 27 January 1999, namely Shorea pinanga and Shorea seminis. The species of meranti group are the main types of natural forest constituents. These types include S.daspyphylia, S. hemsleyana, S. gibbosa, S. kunstteri, S.leprosula, S.macroptera, S.ovalis, S.parvifolia, S. pinanga, $S$. johorensis, S.ovata, $S$.pauciflora, S.pubistyla, S.seminis. Such species have been rare in the Kalimantan forest due to over-exploitation as an economically valuable timber producer. 
Table 1. Phytosociological description of individual tree species of the canopy stratum (perimeter above 10 $\mathrm{cm})$ of the Natural Park PT Badak Bontang.

\begin{tabular}{|c|c|c|c|c|c|c|c|c|c|}
\hline No. & Species & Density & $\begin{array}{l}\text { Relative } \\
\text { Density }\end{array}$ & Frequency & $\begin{array}{l}\text { Relative } \\
\text { Frequency }\end{array}$ & Dominance & $\begin{array}{c}\text { Relative } \\
\text { Dominance }\end{array}$ & $\begin{array}{l}\text { Importance } \\
\text { Value } \\
\text { Index } \\
\end{array}$ & $\begin{array}{c}\text { Index of } \\
\text { Diversity } \\
\text { H' }\end{array}$ \\
\hline 1 & Shorea sp1. & 0.0004 & 1.404 & 0.167 & 1.538 & 0.860 & 2.186 & 5.128 & \\
\hline 2 & Shorea $\mathrm{sp} 2$. & 0.0004 & 1.404 & 0.167 & 1.538 & 0.683 & 1.737 & 4.679 & \\
\hline 3 & Shorea $\mathrm{sp} 3$. & 0.0004 & 1.404 & 0.167 & 1.538 & 0.614 & 1.560 & 4.502 & \\
\hline 4 & Knema latericia & 0.0008 & 2.807 & 0.333 & 3.077 & 0.301 & 0.765 & 6.649 & \\
\hline 5 & Dillenia borneensis & 0.0004 & 1.404 & 0.167 & 1.538 & 0.828 & 2.105 & 5.047 & \\
\hline 6 & Syzygium sp. & 0.0017 & 5.965 & 0.500 & 4.615 & 1.399 & 3.557 & 14.138 & \\
\hline 7 & Arthocarpus anisophylla & 0.0004 & 1.404 & 0.167 & 1.538 & 0.069 & 0.175 & 3.117 & \\
\hline 8 & Memecylon borneensis & 0.0013 & 4.561 & 0.500 & 4.615 & 2.600 & 6.609 & 15.786 & \\
\hline 9 & Shorea kunstleri & 0.0013 & 4.561 & 0.500 & 4.615 & 2.918 & 7.418 & 16.594 & \\
\hline 10 & Ixonanthes reticulata & 0.0004 & 1.404 & 0.167 & 1.538 & 0.456 & 1.158 & 4.100 & \\
\hline 11 & Nothaphobe sp. & 0.0004 & 1.404 & 0.167 & 1.538 & 0.722 & 1.835 & 4.777 & \\
\hline 12 & Shorea parvistipulata & 0.0004 & 1.404 & 0.167 & 1.538 & 0.401 & 1.021 & 3.962 & \\
\hline 13 & Schimawalichii & 0.0004 & 1.404 & 0.167 & 1.538 & 0.272 & 0.691 & 3.633 & \\
\hline 14 & Actinodaphneglabra & 0.0004 & 1.404 & 0.167 & 1.538 & 0.035 & 0.189 & 3.131 & \\
\hline 15 & Octomeles sumatrana & 0.0004 & 1.404 & 0.167 & 1.538 & 0.349 & 0.888 & 3.830 & \\
\hline 16 & Myristia maxima & 0.0004 & 1.404 & 0.167 & 1.538 & 1.274 & 3.240 & 6.182 & \\
\hline 17 & Gonystylus brunnescans & 0.0004 & 1.404 & 0.167 & 1.538 & 0.083 & 0.211 & 3.153 & \\
\hline 18 & Shorealaevis & 0.0004 & 1.404 & 0.167 & 1.538 & 0.707 & 1.798 & 4.740 & \\
\hline 19 & Sp1 & 0.0004 & 1.404 & 0.167 & 1.538 & 0.036 & 0.092 & 3.034 & \\
\hline 20 & $\mathrm{Sp} 2$ & 0.0004 & 1.404 & 0.167 & 1.538 & 0.683 & 1.737 & 4.679 & \\
\hline 21 & Dipterocarpus sp. & 0.0004 & 1.404 & 0.167 & 1.538 & 0.902 & 2.293 & 5.235 & \\
\hline 22 & Xylophia feruginea & 0.0004 & 1.404 & 0.167 & 1.538 & 0.043 & 0.109 & 3.051 & \\
\hline 23 & Ficus sp. & 0.0008 & 2.807 & 0.333 & 3.077 & 1.837 & 4.669 & 10.553 & \\
\hline 24 & Sp3 & 0.0004 & 1.404 & 0.167 & 1.538 & 0.057 & 0.145 & 3.087 & \\
\hline 25 & Nothaphobe sp. & 0.0008 & 2.807 & 0.167 & 1.538 & 0.374 & 0.952 & 5.297 & \\
\hline 26 & Sp4 & 0.0004 & 1.404 & 0.167 & 1.538 & 0.209 & 0.530 & 3.472 & \\
\hline 27 & Durio griffitii & 0.0004 & 1.404 & 0.167 & 1.538 & 0.591 & 1.503 & 4.445 & \\
\hline 28 & Shorea leprosula & 0.0004 & 1.404 & 0.167 & 1.538 & 0.669 & 1.701 & 4.643 & \\
\hline 29 & Horsfieldia sp. & 0.0004 & 1.404 & 0.167 & 1.538 & 0.134 & 0.340 & 3.282 & \\
\hline 30 & Sp5 & 0.0004 & 1.404 & 0.167 & 1.538 & 0.067 & 0.171 & 3.113 & \\
\hline 31 & Sp6 & 0.0004 & 1.404 & 0.167 & 1.538 & 0.104 & 0.264 & 3.206 & \\
\hline 32 & Shorea alutacea & 0.0013 & 4.561 & 0.333 & 3.077 & 2.808 & 7.139 & 14.77 & \\
\hline 33 & $\mathrm{Sp} 7$ & 0.0004 & 1.404 & 0.167 & 1.538 & 0.362 & 0.919 & 3.861 & \\
\hline 34 & Alstoni aiwahingensis & 0.0004 & 1.404 & 0.167 & 1.538 & 0.470 & 1.194 & 4.136 & \\
\hline 35 & Baccaurea stipulata & 0.0004 & 1.404 & 0.167 & 1.538 & 0.072 & 0.182 & 3.124 & \\
\hline 36 & Anthocepalus sp. & 0.0013 & 4.561 & 0.167 & 1.538 & 8.205 & 20.93 & 27.03 & \\
\hline 37 & Sp8 & 0.0004 & 1.404 & 0.167 & 1.538 & 0.409 & 1.039 & 3.981 & \\
\hline 38 & Sp9 & 0.0004 & 1.404 & 0.167 & 1.538 & 0.104 & 0.264 & 3.206 & \\
\hline 39 & Anthocephalus cadamba & 0.0004 & 1.404 & 0.167 & 1.538 & 0.140 & 0.356 & 3.298 & \\
\hline 40 & Boueaop psitifolia & 0.0004 & 1.404 & 0.167 & 1.538 & 0.760 & 1.933 & 4.875 & \\
\hline 41 & Polyialtia sp. & 0.0004 & 1.404 & 0.167 & 1.538 & 0.073 & 0.186 & 3.127 & \\
\hline 42 & Sp10 & 0.0004 & 1.404 & 0.167 & 1.538 & 0.251 & 0.638 & 3.580 & \\
\hline 43 & Fabaceae & 0.0004 & 1.404 & 0.167 & 1.538 & 0.970 & 2.466 & 5.408 & \\
\hline 44 & Sp11 & 0.0004 & 1.404 & 0.167 & 1.538 & 0.352 & 0.895 & 3.837 & \\
\hline 45 & Sp12 & 0.0004 & 1.404 & 0.167 & 1.538 & 0.269 & 0.683 & 3.625 & \\
\hline 46 & Cryptocarya crassinema & 0.0004 & 1.404 & 0.167 & 1.538 & 0.527 & 1.339 & 4.281 & \\
\hline 47 & Ixonanthes sp. & 0.0004 & 1.404 & 0.167 & 1.538 & 0.158 & 0.402 & 3.344 & \\
\hline 48 & Sp13 & 0.0004 & 1.404 & 0.167 & 1.538 & 1.148 & 2.918 & 5.860 & \\
\hline 49 & Shorea slovenii & 0.0004 & 1.404 & 0.167 & 1.538 & 0.234 & 0.595 & 3.537 & \\
\hline 50 & Campnosperma sp. & 0.0004 & 1.404 & 0.167 & 1.538 & 0.040 & 0.102 & 3.044 & \\
\hline 51 & Sp14 & 0.0004 & 1.404 & 0.167 & 1.538 & 0.249 & 0.634 & 3.576 & \\
\hline 52 & Sp15 & 0.0004 & 1.404 & 0.167 & 1.538 & 0.077 & 0.197 & 3.139 & \\
\hline 53 & Sp16 & 0.0004 & 1.404 & 0.167 & 1.538 & 0.243 & 0.617 & 3.559 & \\
\hline 54 & Placordia sp. & 0.0004 & 1.404 & 0.167 & 1.538 & 0.061 & 0.156 & 3.098 & \\
\hline 55 & Dracontomelon dao & 0.0004 & 1.404 & 0.167 & 1.538 & 0.346 & 0.930 & 3.872 & \\
\hline \multirow[t]{2}{*}{56} & Phoebe grandis & 0.0004 & 1.404 & 0.167 & 1.538 & 0.641 & 1.630 & 4.572 & \\
\hline & & & & & & & & & 1.657 \\
\hline
\end{tabular}




\subsection{Vegetation Structure}

\subsubsection{Tree Stratum}

The significance index values of various species in the trees $(>\mathrm{dbh} 10 \mathrm{Cm})$ are presented in Table 1 . It can be seen that tree species of this forest community based on the Importance Value Index (IVI) rankings found are Anthocephalus sp with a value of 27.03 , followed by Shorea kunsteri (16.59), Memecylon borneensis (15.78), Shorea alutaceae (14.7), Syzygium sp. (14.138), and Ficus sp. (10.55). Importance Value Index (IVI) is a quantity that indicates the position (dominance) of a type against other types within a community. The larger a type of IIV, its role in the community is increasingly important.

Referring to this concept, it is clear that high and old aged tree species dominate the forest community. The types of meranti are the main types of community constituents. These types include Shorea daspyphylia, Shorea hemsleyana, Shorea gibbosa, Shorea kunstteri, Shorea leprosula, Shorea macroptera, Shorea ovalis, Shorea parvifolia, Shorea pinanga, Shorea johorensis, Shorea ovata, Shorea pauciflora, Shorea pubistyla, Shorea seminis.

According to Whittaker (1974), the basic assumption in the analysis of standing structures is to predict forest compositions' tendency where a low-density (or negligible) type of stakes and seedlings will eventually disappear from the community stand. Following these assumptions, several species currently encountered in the natural forest of PT Badak are predicted to disappear from stands in the future.

\subsubsection{Sapling Level}

The sapling rate results $(\mathrm{dbh} 2-9.9 \mathrm{~cm})$ in this forest are dominated by pioneer species such as Syzygium spp, Litsea spp, Milletia sericea Baccaurea stipulata, Nauclea $s p$., while the type of Dipterocarpaceae is scarce. This situation indicates the failure of plant regeneration of Dipterocarpaceae. Several factors are causing rebar formation because of the canopy fracture, a drastic change in a microclimate that can cause damage or death of many seedlings. The regeneration failures of these Dipterocarpaceae species in the future will change the structure and composition of plant species and are driven by the dominance of seedlings of a rapidly growing pioneer group, such as Anthocepalus cadamba (Jabon), Litsea sp (Medang), and Syzygium sp (Jambu Hutan).

The type that shows the highest density is Syzygium racemosum with a density of $37.33 /$ ha, followed by Litsea sp. (19,55/ha), Memecylon borneensis (12,89/ha), Diospyros confertifolia (7,55/ha), Bauhinia sp, (7,55/ha), Knema sp. (5,33/ha), Milletia sericea (3,55/ha), Strombosia javanica (3.11/ha), Alseodaphne sp. (2.67/ha), and Arthocarpus sp. (1.78/ha). The success of the seedling level of the pioneer types shows these species can utilize light intensity availability. The relative density and relative density values of the ten types of saplings are presented in Table 2.

Table 2. The density of individual tree species of the sapling as regeneration stratum (perimeter 2-9.9 cm) of the Natural Park PT Badak Bontang.

\begin{tabular}{clc}
\hline No & \multicolumn{1}{c}{ Species } & Density \\
\hline 1 & Syzygium racemosum & 37.33 \\
2 & Litsea sp. & 19.55 \\
3 & Memecylon borneensis & 12.89 \\
4 & Diospyros confertifolia & 7.55 \\
5 & Bauhinia sp. & 7.55 \\
6 & Knema sp. & 5.33 \\
7 & Milletia sericea & 3.55 \\
8 & Strombosia javanica & 3.11 \\
9 & Alseodaphne sp. & 2.67 \\
10 & Arthocarpus sp. & 1.78 \\
\hline
\end{tabular}

\subsubsection{Seedling Level}

For the level of seedling $(\mathrm{dbh}<2 \mathrm{~cm})$ is dominated by the same species as the saplings. The highest density type was Memecylon borneensis with a density of 0.5/ha, followed by Syzygium racemosum (0.195/ha), Litsea firma (0.1667/ha), Maranthes corymbosa (0.1383/ha), Strombosia javanica $(0.1117 / \mathrm{ha})$, Miletia sericea $(0.055 / \mathrm{ha})$, Litsea $\mathrm{sp}$. (0.055/ha), Litsea teysmanii (0.055/ha), Fordia splendidisima (0.055/ha), and Syzygium sp. (0.055/ha). Ten species with the highest relative density and density of the sapling rate are presented in Table 3.

Table 3. Density of individual tree species of the seedling stratum (perimeter $<2 \mathrm{~cm}$ ) of the Natural Park PT Badak Bontang.

\begin{tabular}{clc}
\hline No & \multicolumn{1}{c}{ Species } & Density \\
\hline 1 & Memecylon borneensis & 0.500 \\
2 & Syzygium racemosum & 0.195 \\
3 & Litsea firma & 0.166 \\
4 & Maranthes corymbosa & 0.138 \\
5 & Strombosia javanica & 0.111 \\
6 & Litsea sp. & 0.055 \\
7 & Milletia cerise & 0.055 \\
8 & Syzygium sp. & 0.067 \\
9 & Litsea teysmanii & 0.005 \\
10 & Fordia splendidisima & 0.005 \\
\hline
\end{tabular}




\subsection{Diversity}

In Table 1, we can be seen that the species diversity after 40 years old in a natural park in the industrial park as remnant is relatively small, i.e., $H^{\prime}=1.657$. From the results of monitoring the biodiversity of plants in Botanical Park of PT Badak Bontang, seen the existence of the dominance of certain species due to the growth of seedling level and sapling of several types of plants to reach climax. The composition of forests will occur dynamically each year, where declines or deaths are more likely to occur due to parent tumbling trees on saplings and stakes, climate change, human activities on the forest, and plant-level competition.

The succession process occurs gradually and depends on the forest environment's state, so it takes a long time to reach the climax. Succession in the early stages begins with the formation of gaps, stimulating the pioneer plants under the fallen breeding canopy to harness the sunlight for growth. In the process of succession to its climax, it will replace the lost brooding individuals. In the process of succession, the dead parent tree will not always be replaced by the same individual species. This is influenced by the type and competition of seedlings and saplings that lie beneath the dead parent. Types of parent trees with a high natural seedling ability will have a high probability of dominating the next climax composition. In contrast, sires with low raw seedling power will gradually be eliminated or lost in this forest's composition.

\section{CONCLUSION}

(1) The remnant natural forest community in PT Badak LNG Bontang is dominated by tree species of high canopy structure and old age. The types of Dipterocarpaceae (meranti) are the main types of community constituents. These types include Shorea daspyphylia, Shorea hemsleyana, Shorea gibbosa, Shorea kunstteri, Shorea leprosula, Shorea macroptera, Shorea ovalis, Shorea parvifolia, Shorea pinanga, Shorea johorensis, Shorea ovata, Shorea pauciflora, Shorea pubistyla, Shorea seminis.

(2) Based on IVI rankings, respectively, Anthocephalus sp. with a value of 27.03, followed by Shorea kunsteri (16.59), Memecylon borneensis (15.78), Shorea alutaceae (14.77), Syzygium sp. (14.138), and Ficus sp. (10.55).

(3) The level of seedlings in natural forests is dominated by pioneer species such as Memecylon borneensis, Syzygium spp., Litsea spp. The type of Dipterocarpaceae seedling is scarce. The regeneration failures of Dipterocarpaceae species in a tropical forest remnant in this place for the future will alter the structure and composition of the plant species and are compelled by the dominance of seedlings of pioneer groups.

\section{ACKNOWLEDGMENTS}

The author would like to thank Directorate-General for Research and Community Services has funded this research and all those who have helped both in the field and in the laboratory.

\section{REFERENCES}

[1] D.S. Wilcove, C.H. McLellan, A.P. Dobson. Habitat fragmentation in the temperate zone, in: M. Soul'e, Conservation Biology, Sunderland, MA, Sinauer, 1986, pp. 237-256.

[2] D.A. Saunders, R.J. Hobbs, C.R. Margules, Biological consequences of ecosystem fragmentation: a review, Conserv Biol, 5, 1991, pp. $18-32$.

[3] R. Aerts, K. Hundera, G. Berecha, P. Gijbels, M. Baeten, M. van Mechelen, M. Hermy, B. Muys, O. Honnay, Semi-forest coffee cultivation and the conservation of Ethiopian Afromontane rainforest fragments, For Ecol Manage, 261, 2011, pp. 1034 1041 .

[4] J.E. Duffy, Why biodiversity is important to the functioning of real-world ecosystems, Front Ecol Environ, 7(8), 2009, pp. 437-444.

[5] R. Costanza, R. d Arge, R. deGroot, S. Farber, M. Grasso, B. Hannon, K. Limburg, S. Naeem, R.V. Oneill, J. Paruelo, R.G. Raskin, P. Sutton, M. van den Belt, The value of the world's ecosystem services and natural capital, Nature, 387(6630), 1997, pp 253-260. 